\title{
Evidence-Based Policies in Higher \\ Education: Data Analytics, Impact \\ Assessment and Reporting \\ [Overview Paper]
}

\author{
Jamil Salmi
}

\section{Introduction}

Universities are among the oldest well-established institutions in modern history. For centuries, they were able to operate without any major transformation, as illustrated by the following quote:

\begin{abstract}
About eighty-five institutions in the western world established by 1520 still exist in recognizable forms, with similar functions and with unbroken histories, including the Catholic Church, the parliaments of the Isle of Man, of Ireland and of Great Britain, several Swiss cantons, and seventy universities. Kings that rule, feudal lords with vassals, and guilds with monopolies are all gone. These seventy universities, however, are still in the same locations with some of the same buildings, with professors and students doing much the same things, and with governance carried on in much the same ways.
\end{abstract}

Clark Kerr, former president of the California state university system

But the image of stability and continuity associated with the concept of the University has been recently shattered. The French philosopher Paul Valery observed with nostalgia that "the trouble with our times is that the future is not what it used to be". This is particularly true in the realm of higher education, which is in great flux. A recent report published in the United Kingdom proposed the image of "an avalanche" to describe the radical changes affecting tertiary education in many parts of the world (Barber et al. 2013). Indeed, powerful transformative forces are challenging higher education systems and institutions all over the world.

First, a growing number of rupture factors are at play in transforming the ecosystem in which higher education institutions are operating, drastically influencing how they perform their teaching and research functions. Among these rupture factors are technological innovations, such as flipped classrooms for interactive learning, mass online open courses (MOOCS) reaching hundreds of thousands of

\footnotetext{
J. Salmi ( ()

Global Tertiary Education Expert, Bogota, Colombia

e-mail: jsalmi@tertiaryeducation.org
}

(C) The Author(s) 2015

A. Curaj et al. (eds.), The European Higher Education Area,

DOI 10.1007/978-3-319-20877-0_49 
students all over the world, new forms of competition from for-profit and corporate universities that provide professional qualifications closely linked to labour market needs, and new accountability modalities like the global rankings, which allow to measure and compare the performance of universities across all continents (Salmi 2013).

Second, as a result of the 2007 financial downturn, the higher education sector in most regions of the world has been adversely affected by serious crisis factors. In the US, for example, the level of public support for tertiary education has been reduced substantially in nearly every state - 48 out of 50 over the $2008-13$ period - under the combined impact of the economic recession, federal mandates to fund other sectors such as healthcare, and the reluctance to increase state taxes (Miller 2013). In Europe, 13 out of the 20 university systems that the European Universities Association has been monitoring since the beginning of the financial crisis have experienced overall budget decreases in real terms between 2008 and 2012, nine of them of more than $10 \%$ (EUA 2013). The cuts have been even more severe throughout the developing world and in transition countries, with the aggravation of falling household incomes and soaring graduate unemployment rates.

In this rapidly changing context, higher education has come under increased scrutiny from all quarters of society, industry and government. Students are concerned about the standing of the universities they plan to enrol into, especially when going to study overseas. Employers are preoccupied about the performance of the local higher education institutions. And politicians have begun to consider the position of their country's top universities in the global rankings as a vital indicator of national prestige.

As a result, higher education has found itself at the heart of the national public agenda in a growing number of countries. The high stakes involved have forced decision-makers to consider more systematically the role of universities as instruments of economic development and social mobility, making it all the more important to ground higher education policies carefully on evidence about what works. Similarly, at the institutional level, universities and other types of higher education institutions have learned to guide their transformative efforts with a more thorough analysis of their strengths and weaknesses and a deeper understanding of the factors behind the results of successful universities.

\section{Overview of the Contribution of the Papers to the Theme}

Higher education policy has two special dimensions that set it apart from other public policy domains. First, everyone is an expert on the topic by the mere fact of being a university graduate. This is one of the fields with the highest proportion of self-appointed professional authorities. But, as Andreas Schleicher observed, "without data, you are just another person with an opinion." 
Second, higher education policy is the realm of controversy by excellence. As Machiavelli wrote in his famous political manifesto, the Prince, "there is nothing more difficult to take in hand, more perilous to conduct, or more uncertain in its success than to take the lead in introducing a new order of things". While this observation is true of any political reform, it is particularly resonant in the case of higher education reforms. Universities are among the most conservative cultural and organizational institutions, with extremely vocal, yet highly transitory constituencies, including faculty and the students. These groups can effectively mobilize themselves against policy changes likely to challenge established practices and vested interests. This is often the case when it comes to financing or governance reforms such as the introduction of tuition fees, reductions in social benefits for the students, the elaboration of a transparent funding formula for public resource allocation, changes in the mode of selection of university leaders, or mergers among existing institutions to achieve economies of scale.

Therefore, instead of organizing higher education policy on the basis of a combination of ideology and personal experience, it is essential to build a body of relevant knowledge that can help define the range of reform options and make decisions suitably based on available evidence about causes and effects. The four articles included in this sub-theme on evidence-based higher education policy are good examples of the types of relevant studies that can serve to enrich the perspective and knowledge of policy-makers at the national level and university leaders at the institutional level. As the following list shows, the first three look at policy issues at the system-wide level, whereas the last one examines the consequences of the Bologna process on a specific university:

- Higher Education Research in Europe (Ulrich Teichler);

- Do changes in cost-sharing have an impact on the behaviour of students and higher education institutions? Evidence from nine case studies (Dominic Orr);

- Does research influence educational policy? The perspective of researchers and policy-makers in Romania (Georgeta Ion and Romita Iucu);

- The Impact of the Bologna Process and German Higher Education Reforms on Faculty Work at the University of Potsdam: A Case Study (Christen Cullum Hairston).

After retracing the history of the field of higher education as an academic research field and its stages of development in the European context, showing that it has remained up to the present a small academic area, Professor Teichler emphasizes the growing interest in higher education policy in recent years, as a consequence of financing and governance reforms and the multiplication of assessment activities by national governments and international organizations. His analysis shows that higher education research has remained essentially national in focus, without sufficient evidence-based work to establish the impact of national policies on higher education institutions. It finds also a paucity of work in international comparative research on higher education. 
Professor Teichler notes, further, the lack of clarity and agreement in the delineation of the specific academic areas that define higher education policy, observing that it is an heterogeneous research domain and "a field of expertise with very fuzzy borderlines between research on the one hand, and consultancy, administrative oversight, evaluation and other search for evidence on the other hand." This leads him to ask the following two questions: "to what extent do these conditions serve the enhancement of higher education research? And to what extent do these conditions of knowledge generation serve a desirable future of higher education?" His answer is guardedly optimistic. He expresses the view that the joint perspective of higher education researchers and higher education policy analysts may enrich the understanding of the complex evolution of higher education systems and institutions.

Dr. Orr's chapter presents the methodology and findings of a recent major study on cost-sharing, which was commissioned by the European Union as an impact study on changes to the balance of higher education costs between public grants and private revenues. The purpose of the study was to provide a basis for a better understanding of reforms to higher education funding and their consequences.

This work on cost sharing was conducted on the basis of standardized case studies in nine countries: Austria, Canada, England, Finland, Germany, Hungary, Poland, Portugal, and South Korea. Following the approach successfully applied to analyzing higher education reform by Cerych and Sabatier in their seminal work from the mid-1980s, the national case studies enabled to reflect both the influence of each specific context and the general impact of changes in cost sharing policies (Cerych and Sabatier 1986).

The analysis of the nine case studies led to the following general findings. First, public funding to higher education institutions did not decrease overall as cost sharing increased, not even on a per-student basis. Second, traditional universities were less agile in responding to changes in student demand patterns as a result of increased cost sharing. Finally, it is very difficult to attribute any adverse equity effect to increased cost sharing as the demand for higher education has continued to rise everywhere in the last two decades, even in countries like England where tuition fees are high.

Professors Ion and Iucu focus on the relationship between educational research and policy-making process, using the case of Romania as specific example. The paper focuses first on the production of research and its relevance to policy making. It then examines the views of policy makers about research products and knowledge dissemination. Finally, it discusses the obstacles to the transfer of research findings to policy making.

Relying on in-depth interviews of researchers and policy-makers, as well as questionnaires administrated to postgraduate students in Romanian universities, the authors find a large disconnect between education research and policy-making. The first major barrier is the fact that the quality and relevance of higher education research leaves much to be desired. The absence of proper communication and 
dissemination mechanisms is another important obstacle. Based on these findings, Professors Ion and Iucu make a series of recommendations to improve the appropriateness of research and develop adequate channels of communication to ensure better relationships between research and decision-making.

The last paper, prepared by Professor Hairston, investigates the impact of the Bologna process and ensuing reforms in the German higher education scene on the role and work of academics. This case study of the University of Potsdam, based on in-depth interviews of 25 professors, seeks to provide a detailed account of the transformation of teaching and learning under the influence of the Bologna process.

The main finding of this research is that German academics are very resilient; they have adapted well to the many changes caused by the Bologna process: increased competition, new pay scale, introduction of junior professorships, increased enrolment and growing time demands in teaching and research, changing mentality and behaviour of students, and a greater authoritative management of their professorial roles. At the same time, the academics feel that "Bologna threatens the Humboldtian ideal of the university by reducing the responsibilities in the professional roles of teaching, research, and service and regulating a historically unregulated system. ... Professors voiced their frustrations with the implementation of the Bologna Process especially in terms of ECTS points, modular definitions, student requirements, and a general lack of agreement across departments." The article concludes by outlining the need for the leaders of the University to work carefully at clarifying and harmonizing the new rules for organizing the courses and the teaching in accordance with the Bologna principles.

\section{Conclusion}

The American journalist H.L. Mencken once wrote "there is always an easy solution to every human problem — neat, plausible, and wrong." This observation is very relevant to the realm of higher education policy, where the stakes are so high and the power of ideology so strong. It highlights the importance of learning systematically from careful evaluations of the impact of reforms in order to inform policy-making. At the national level, policy analysis and decision-making must be based on a careful understanding of the situation and the potential effect of each reform option. At the institutional level, universities must develop their institutional research capacity, monitor the main elements of their performance, and make development decisions based on the lessons of experience.

Learning from the experience of others, nationally and internationally, is not about copying or imitating policies from other institutions or countries. But the lessons of experience can help understand what works and what does not work under various conditions and circumstances, in order to increase the probability of success and avoid repeating the mistakes of others. 
To use the results of evidence-based research effectively, it is important to maintain the objectivity of the researchers involved in policy analysis and impact evaluation. With the rise of contracted research and consultancies, careful rules should be defined and enforced to avoid risks of conflict of interest between the researchers and the contracting agencies.

Finally, the recent higher education crisis in Chile is a good example of the dangers of not conducting an evidence-based policy debate. What started in 2011 as a demand by secondary school students that their free transport pass be extended to the entire calendar evolved into a full-blown confrontation between student organizations and the entire government. The leading factions of university students ended up demanding the abolition of fees at all levels of the education system. President Bachelet was elected in December 2013 on a platform promising free higher education for all.

At no time in the debate was there a technical discussion of the pros and cons of Chile's higher education financing model. Even though evidence shows that the Brazilian model of free higher education in elite public universities is much more unequal than the Chilean model of tuition fees associated with scholarships and loans for low-income students, the entire discussion has been driven by opposite philosophical views. Instead of debating the pros and cons of the present model, and reaching a consensus on the adjustments needed to remove existing elements of dysfunction (e.g., increased public funding for higher education, extension of scholarships to all eligible students from Quintiles I and II, unification of the two existing student loan schemes, reduction of unsustainable debt burden, etc.), the decision was made to eliminate fees altogether.

With this type of reform backtracking, the government faces the risk of abandoning some of the more innovative features of the Chilean higher education system, which is one of the best performing systems in Latin America today. While this could help resolve the crisis in the short term, it would likely have long-term adverse consequences, as illustrated by the Irish example of fee abolition in the 1990s. Ireland was the first Western European country that introduced tuition fees in the beginning of the 1990s, which helped improve the financial sustainability of the higher education system. In 1996, however, the new Labour government abolished the fees to fulfil electoral promises. As a result, inequality rose because, in the absence of fees, the poorer part of the population ended up subsidizing free studies for the middle class, but in addition quality suffered overall for lack of sufficient public funding.

Sound policy reform based on good technical analysis is not guaranteed to satisfy all stakeholders or quell political protest. However, when governments want to meet the challenge of staying ahead of the curve of public opinion, they may find it easier to engage with civil society around conference tables rather than in the streets.

Open Access This chapter is distributed under the terms of the Creative Commons Attribution Noncommercial License, which permits any noncommercial use, distribution, and reproduction in any medium, provided the original author(s) and source are credited. 


\section{References}

Barber, M., Donnelly, K., \& Rizvi, S. (2013). An avalanche is coming: Higher education and the revolution ahead. Retrieved from http://med.stanford.edu/smili/support/FINAL\%20Avalanche \%20Paper\%20110313\%20(2).pdf

Cerych, L., \& Sabatier, P. (1986). Great expectations and mixed performance: The implementation of higher education reforms in Europe. The implementation of higher education re-forms in Europe. Stoke-on-Trent: Trentham Books.

EUA, European University Association (2013). EUA's public funding observatory. Retrieved from http://www.eua.be/Libraries/Governance_Autonomy_Funding/EUA_PFO_report_2013. sflb.ashx

Miller, R. (2013). Rising tuition and student debt, uncertain job opportunities: Engineering education in challenging financial times. Needham: Olin College of Engineering.

Salmi, J. (2013). If ranking is the disease, is benchmarking the cure? In P. T. M. Marope, P. J. Wells, \& H. E. (Eds.), Rankings and accountability in higher education: Uses and misuses (pp. 235-256). Paris: UNESCO. Retrieved from http://unesdoc.unesco.org/images/0022/ 002207/220789e.pdf 